\title{
COMPARATIVE STUDY OF THE COMPONENTS OF THE QUALITY OF WORKING LIFE
}

Nélida del Carmen Castellano

School of Economics

National University of Córdoba

Córdoba, Córdoba, Argentina

nelicast@gmail.com

\section{Esteban Damián López}

School of Economics

National University of Córdoba

Córdoba, Córdoba, Argentina

amian.lopez@quappro.com

Reception date: 08/28/2020 - Revision date: 09/07/20 - Revision date: 10/06/2020 - Approval date: 12/15/2020

DOI: https://doi.org/10.36995/j.visiondefuturo.2021.25.01.003.en

\section{ABSTRACT}

Our line of research in 17 years has been Total Quality and its problems in SMEs in Córdoba. Until now, we had not studied the concept of Quality of Working Life (QWL).

This project is part of a larger one that integrates the Current Population Challenges Program, where we have included the QWL, since we understand that a current population challenge is to study the factors that affect it: unemployment, underemployment, labor precariousness, economic crisis, gender issues that have not been overcome in years, preconceptions about the lower capacity of female versus male decision making, among others. In recent months, an additional factor, unthinkable and serious, as is the quarantine by the Covid-19, has made the work of people and therefore this concept even more complex.

The study of QWL is a young field, where the authors do not agree on identical dimensions and variables for its measurement. As a first stage, we have compared updated studies and added factors by impact of Total Quality and Covid-19 quarantine, to build a superior model useful for decision making and a questionnaire, which we have tested in some organizations.

KEY WORDS: Quality of Working Life; Dynamic processes; Total quality; Continuous Improvement; Teleworking.

\section{INTRODUCTION}

This project is part of the Current Population Challenges Program, where we have included the Quality of Working Life (QWL), because we understand that a current population challenge is to study the factors that affect it: unemployment, underemployment, job insecurity, economic crisis, gender issues that have not been overcome in years, preconceptions about the lower capacity of female versus male decision making, among

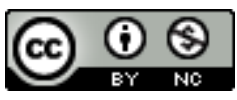

Los trabajos publicados en esta revista están bajo la licencia Creative Commons Atribución NoComercial 2.5 Argentint 
others. In recent months, an additional factor, unthinkable and serious, as the Covid-19 pandemic, has made the work of people and therefore this concept even more complex.

When searching for CVL background, there are numerous studies and researches, with data surveys in the scope of organizations of specific branches (there are numerous of the health sector), which have special interest in using the concept of the QWL of their collaborators for the diffusion of their good management. This is a young field of study, in which the various authors do not agree on which the appropriate dimensions and variables for measuring the QWL are. Therefore, we had to analyze several operational models and complete them with other dimensions, so that it may be of real use in the decision-making process of the organizations' managers.

We consider this project as the first part of another one that will have a greater scope and that will also address the gender differences in the QWL which have not yet been solved.

\section{Research questions}

- How many dimensions of study does Quality of Working Life have?

- What are the main factors or components that determine Quality of Working Life? Do they all have the same relative weights?

- What impact do the changes in the dynamic processes caused by Total Quality, especially Continuous Improvement, have on the Quality of Working Life?

- Are there changes in the work of people caused by the Covid-19 quarantine and how do they affect the Quality of Working Life?

\section{Research problem}

From the above questions considered as triggers for our concerns for this inquiry, it is possible to extract a more comprehensive question to present it as the research problem, which is set out below:

What are the dimensions and factors, or components, that best explain and measure Quality of Working Life and what other components have emerged from the changes in the Dynamic Processes (Continuous Improvement) and from the Covid-19 quarantine?

\section{Overall Objective}

To study the dimensions and factors or components that best explain and measure the Quality of Working Life. In addition, we want to know what new factors have emerged from

\footnotetext{
"Visión de Futuro" Año 18, Volumen No 25 N 1, Enero - Junio 2021 - Pág 91 -106

URL de la Revista: http://visiondefuturo.fce.unam.edu.ar/index.php/visiondefuturo/index

URL del Documento: https://visiondefuturo.fce.unam.edu.ar/index.php/visiondefuturo/issue/view/19

ISSN 1668 - 8708 - Versión en Línea

E-mail: revistacientifica@fce.unam.edu.ar
} 
the changes in Dynamic Processes (Continuous Improvement) and the Covid-19 quarantine, in order to elaborate a superior model.

\section{Specific Objectives}

- Investigate the dimensions and the factors or components that determine the Quality of Working Life.

- know the impact on the Quality of Work Life of the changes that occur in the Dynamic Processes, for example the Continuous Improvement.

- Identify new factors affecting the work of people originating from quarantine by Covid-19.

\section{DEVELOPMENT}

\section{A. Conceptual Framework}

\section{Concept of Quality of Working Life (QWL)}

The origins of the Quality of Life at Work (QOL) movement can be traced to the work of the Tavistock Institute of Human Relations in London in 1947, whose researchers applied a socio-psychological approach (application of sociology and psychology to the study and resolution of social problems).

The concept as such emerged in the seventies, when an intense concern appears to improve the workers' work environment and the experiences of the work itself, gradually shaping a movement oriented towards the study and improvement of the QWL. In the U.S., this movement originated in a series of conferences sponsored in the late 1960s and early 1970s by the U.S. Department of Labor and the FORD Foundation, to address workers' protests against the dehumanization of labor relations, following the organizational productivity and welfare of workers. In Europe, the QWL movement appears united with the movement for the Humanization of Labor with the common trunk in socio-technical theory and with a greater emphasis on the welfare of workers, as the following classic authors wrote: Maccoby, 1976; Larouche et al., 1983; Mateu, 1984; Sun, 1988; De la Poza et al. 1988 , which we do not include in references because of its antiquity.

In its broadest sense, the QWL includes all the conditions related to work, from schedules, salary, work environment, benefits and services, career possibilities and human relations, which are relevant for work satisfaction and motivation. It also covers the experiences of individuals in each job. In short, the aspects of human experiences and

\footnotetext{
"Visión de Futuro" Año 18, Volumen No 25 N 1, Enero - Junio 2021 - Pág 92 -106

URL de la Revista: http://visiondefuturo.fce.unam.edu.ar/index.php/visiondefuturo/index

URL del Documento: https://visiondefuturo.fce.unam.edu.ar/index.php/visiondefuturo/issue/view/19

ISSN 1668 - 8708 - Versión en Línea

E-mail: $\underline{\text { revistacientifica@fce.unam.edu.ar }}$
} 
organizational objectives must be included, that is, under two major theoreticalmethodological perspectives: the quality of life of the work environment and the psychological QWL perspective.

The objective of the QWL is to determine the aspects of the work that affect the quality of life of a person, for that reason work in its multiple expressions in the being and doing of a person that go beyond the salary, therefore, it can be affirmed that it is of multidimensional character, in addition, it implies the reproduction of society, the construction of identity and sense of belonging, the possibility of recognition and social satisfaction.

In the international debate, the qualities of employment and decent work have gained importance since the $90 \mathrm{~s}$, especially by institutions such as the ILO and the UN. (Weller and Roethlisberger, 2011). The ILO in 2012, defined that work is a source of personal dignity, family stability, peace in the community, democracies that act for the benefit of all, and economic growth, which increases opportunities for productive work and business development.

Blanch i Ribas is one of the current European authors concerned with providing answers, more or less innovative, to the old question of how to achieve full employment. Growth, competitiveness, employment and quality of life, are the fundamental aspects that he analyzes. He tries to define the general terms of the contemporary debate about the impact of the new socio-labor order on the quantity and quality of available employment and on social and psychological well-being. He considers labor stability as a key to the quality of life. (Blanch i Ribas, 2003).

\section{Impact of Total Quality in the Administrative Discipline}

Total Quality or Total Quality Management (TQM) applied especially in the '90s has brought deep changes to the administrative discipline. No other management philosophy or methodology has had such a strong impact on management as Total Quality has. This topic has been one of our objects of study, elaboration of articles and exhibition in events, from 2008 onwards.

It is a topic whose theoretical framework takes concepts from authors of Administration and Total Quality Management, such as: Hill, Ch. and Jones, G. (2011), Evans, J. and Lindsay, W. (2005), Fea, U. (1995), Pfeffer, J. (1995), Riccardi, R. (1993) and Fernández, J. A. (2005). It also adds concepts incorporating authors of Organizational Behavior, among others: Chiavenato, I. (2007), Davis, K. and Newstrom, J. (2003), Gore, E. (2006) and Robbins, S.P. (2017). Most of these works have been updated by their authors in recent years, as they are in permanent consultation.

\footnotetext{
"Visión de Futuro" Año 18, Volumen N²5 N 1, Enero - Junio 2021 - Pág 91 -106

URL de la Revista: http://visiondefuturo.fce.unam.edu.ar/index.php/visiondefuturo/index

URL del Documento: https://visiondefuturo.fce.unam.edu.ar/index.php/visiondefuturo/issue/view/19

ISSN 1668 - 8708 - Versión en Línea

E-mail: revistacientifica@fce.unam.edu.ar
} 
The following groups of changes caused by the philosophy of Total Quality in Administration are highlighted, which directly impact the Quality of Working Life as we will see later:

1. Changes in Organizational Structure

2. Changes in the Functions of the Administrative Process

3. Changes in the elements of the Strategy

4. Changes in Dynamic Processes

\section{Changes produced in the Dynamic Processes}

For this work we are interested in deepening in the variables that shape human behavior (studied by behaviorism) called Dynamic Processes. These refer to the fluids that circulate through the structure of an organization, such as: leadership, motivation, conflict and communication. From the Total Quality Management, all of them have been modified with the superior objective of generating the Quality of Working Life. The main dynamic processes identified are the following:

- Leadership (Authority and delegation)

- Motivation

- Conflict

- Communication

- Information

- Permanent training

- Continuous learning

Leadership has had to be adapted to work in teams where leadership differs substantially from the management of individuals, who could be divided to achieve the leader's goals. The synergy generated in the high performance teams formed to fulfill the principles of Total Quality Management, exceeds the knowledge of each person and even the leader himself. Leadership must adapt to new leadership styles, such as the participation and involvement of all personnel in pursuit of the higher goal of customer satisfaction. Nowadays, we talk about Lean Leadership, which is the one necessary to conduct the processes in which the Lean methodology has been applied (manufacturing, offices and services) (U. Dombrowski, T. Mielke, 2014).

Motivation, an inseparable companion of leadership, must follow the new guidelines of Total Quality and be very transparent and genuine. Kaoru Ishikawa always said in her courses to managers that when Quality enters an organization, there is no more deceit and

\footnotetext{
"Visión de Futuro" Año 18, Volumen No 25 N 1, Enero - Junio 2021 - Pág 92 -106

URL de la Revista: http://visiondefuturo.fce.unam.edu.ar/index.php/visiondefuturo/index

URL del Documento: https://visiondefuturo.fce.unam.edu.ar/index.php/visiondefuturo/issue/view/19

ISSN 1668 - 8708 - Versión en Línea

E-mail: revistacientifica@fce.unam.edu.ar
} 
lies. The human needs that play on motivation in the organization are numerous and the most effective method of analysis (but also the most difficult) must be based on communication between different colleagues: the cadres (hierarchical levels) must know how to listen and open a dialogue with the employees. True Continuous Improvement must take place in the basic daily task and in all departments. It must result from a culture of improvement. The daily improvement must become a natural behavior of all employees and directed by the will of personal development and sense of achievement and not by monetary advantages, it is a superior motivation factor.

The conflict is no longer avoided or hidden, but requires strategic treatment to eliminate its causes, or, once produced, reach a consensual solution using, as far as possible, the techniques of negotiation that tend to obtain win-win type results, after deeply knowing the needs of the parties in conflict.

Communication is now multidirectional and not just top-down, as has been asserted for many years. Upward and lateral communications are also encouraged, that is, between peers with whom work teams are formed. The process of communication implies knowing the interlocutors and listening to them, which is not possible without a good internal climate; it follows that the internal climate and communication are very interdependent. Furthermore, communication must be established in a spirit of sincerity and total transparency, with a clear objective known to all.

The information of interest to all members of the organization must circulate naturally and freely. After the implementation of Total Quality Management, the secrets and the implicit objectives and strategies, which only exist in the mind of the owner or manager, come to an end. The dissemination of information becomes an obligatory function for the hierarchical cadres.

The permanent training merged as a consequence of a cultural change, where great importance is given to the training of the personnel in all its strata. The ultimate meaning is that training has no end; new knowledge and skills must always be learned. The objective of the system is also used to evaluate the development of the employee. Before we build cars, we build people; this proverbial Toyota phrase illustrates very well the great importance of employee development. Therefore, employee development must be at the top of the system's objectives. The process can only be as good as the employee. For this reason, both must be developed equally. (U. Dombrowski, T. Mielke, 2014).

The continuous learning is another expression of the cultural change, which transforms the employees into beings deeply interested in all the processes of the organization and in its continuous improvement (Kaizen), with a permanent curiosity in the activities that surround 
them and in the possibility of change and optimization. Learning must take place in short cycles. Problem solving and learning must be done in a standardized way and based on the PDCA or PHEA cycle (Plan, Do, Evaluate and Act). Numerous regular repetitions and a science experiment approach to the various tasks are essential. (U. Dombrowski, T. Mielke, 2014).

In the Industrial Era, successful organizations were those that increased their financial capital, which made them, grow and expand. Today, however, successful organizations are extremely agile and innovative. We live in the Information Era and financial capital leaves room for intangible and invisible assets, called Intellectual Capital. One of the main components of Intellectual Capital is Human Capital, that is, capital made up of people, talents and skills. The physical capital is depreciated with the use, but the value of knowledge increases every day more; the flow of knowledge of a person does not diminish, it is complemented with the one of the others, that is why the dynamic processes of permanent training and continuous learning acquire so much importance, as features of a democratic and driving organizational culture.

Riccardi (1993), a pioneer in management studies in Argentina, defended that Total Quality Management should apply Total Quality Management to processes and products, but also to human resources and the work environment, in order to generate the Quality of Working Life, without which the first one is not achieved, and he left already in those years, definitively installed the concept of the Quality of Working Life.

Pfeffer (1995) made clear his opinion about the importance of people in the organization and stated that both Quality Management and Change Management can only be successfully achieved through human resources. This thought reveals the greatest intention of recognition for the workers. He counts among his followers prestigious authors such as: Stephen Robbins, Martha Alles, Andrew Dubrin, Enrique Franklin and Mario Krieger. Recognition is one of the main factors or components of Quality of Working Life.

\section{B. State of the Art}

We have reviewed the publications of the last 10 years that try to determine the components or factors that impact the Quality of Working Life and to establish a measurement. Among these publications, we have selected those that provide us with contributions to the conceptual framework and the measurement methodology.

From the selected publications we took the most complete tables with which we carried out the comparative analysis, with the purpose of integrating the greater number of dimensions in a superior model to investigate and measure the complex concept of the

\footnotetext{
"Visión de Futuro" Año 18, Volumen $N^{\circ} 25$ N 1, Enero - Junio 2021 - Pág 92 -106

URL de la Revista: http://visiondefuturo.fce.unam.edu.ar/index.php/visiondefuturo/index

URL del Documento: https://visiondefuturo.fce.unam.edu.ar/index.php/visiondefuturo/issue/view/19

ISSN 1668 - 8708 - Versión en Línea

E-mail: revistacientifica@fce.unam.edu.ar
} 
Quality of Labor Life properly. We also added a publication on the effects of quarantine by Covid-19 on people's work.

Contributions of the selected publications:

a) González-Hidalgo-Salazar-Preciado (2010): Elaboration and Validation of the Instrument to Measure Quality of Life at Work "CVT-GOHISALO. The authors have made what the title of the article says, in a 7-dimensional instrument with 74 variables to measure the CVT. This model has been widely used until now because it has been validated and it is very complete. However, the extension of the instrument (74 items) has always been presented as an inconvenience, which led other researchers Pando, González, Aranda and Elizalde (2018) to develop a short version (31 items), which was also validated.

b) Granados, Isabel (2011): Quality of Working Life: History, Dimensions and Benefits The author has made a theoretical compilation of the history of the Quality of Working Life, as well as the various concepts that have been developed around it, reviewing the most prominent works. The study of the Quality of Working Life has been approached basically under two major theoretical-methodological perspectives: the quality of life of the working environment and the perspective of the psychological QWL. The perspective of the quality of the work environment pursues the objective of achieving an improvement in the quality of life through the achievement of organizational interests. On the other hand, the perspective of the quality of psychological working life shows greater interest in the worker. The variables studied are classified as follows: Objective conditions: they are given by the analysis of variables referred to the physical, technological, contractual and productive environment. While the Subjective Conditions refer to the private sphere and the labor world, organization and management function and benefits.

c) Martinez-Oviedo-Luna (2013): Working conditions that impact on working life. They studied the variables of working conditions that impact on the Quality of Working Life, collecting publications over 20 years. They propose a conceptual classification scheme (ECC) of the factors of working conditions:

1. Environmental conditions: it involves aspects such as work satisfaction, work risks, workload, among others. 2. Ergonomic conditions: related to the work site where the employee develops his activities and the well-being that it offers him. 3. Economic Conditions: aimed at the perception of the worker with respect to the salary received.

They also mention: the psychosocial climate and the QWL and include factors such as the conciliation of work and family life, work involvement and state of mind. And finally: gender equality, safety and health at work, flexibility at work, training and promotion

\footnotetext{
"Visión de Futuro" Año 18, Volumen No 25 N 1, Enero - Junio 2021 - Pág 91 -106

URL de la Revista: http://visiondefuturo.fce.unam.edu.ar/index.php/visiondefuturo/index

URL del Documento: https://visiondefuturo.fce.unam.edu.ar/index.php/visiondefuturo/issue/view/19

ISSN 1668 - 8708 - Versión en Línea

E-mail: revistacientifica@fce.unam.edu.ar
} 
possibilities, organization of the working day and personal life, diversity and nondiscrimination.

d) Becerra Gualdrón (2015): Quality of Employment with a Gender Perspective: Proposal for a Conceptual Framework. The author affirms that the analysis of the QWL with a gender focus has a scarce approach, for this reason she presents a very complete conceptual framework for its analysis.

The data provided by the authors mentioned in the extensive review are very useful, the most important being Weller and Rothlisberger (2011) from ECLAC, with the dimensions for Latin America. Finally, the author proposes a measurement of the QWL based on this work and elaborates a questionnaire with two parts: for the company and for the individuals, which is based on both subjective perceptions and objective data, considering the multidimensionality of the QWL concept.

e) Cruz Velazco (2018): The Quality of Working Life and the Study of Human Resources: A Reflection on their Relationship with Organizational Variables. He wants to determine the main variables of the QWL. He searched these following terms in scientific articles published in the last 7 years: QWL, organizational variables, $\mathrm{QWL}$ and variables, QWL and relationships, reviewing the most recognized databases. From this analysis he obtained tables with relationships between independent and dependent variables that affect the QWL. He concludes that, because of the variety of challenges to worker welfare, an integrated approach to research is needed that can help improve the perceived Quality of Working Life.

f) Esbry, G. (04/07/2020): Teleworking: A new challenge for the world of works. La Voz del Interior, Journal of Cordoba. Argentina. The Covid-19 quarantine has forced us to change many of our daily habits, including work; we do it from home with the telework modality, also called home-office. According to the Labor Indicator Survey (EIL) of the Ministry of Labor of the Nation, before the pandemic, less than $8 \%$ of the workers did it remotely, $70.4 \%$ were young men employed in Technological Services. Now more than $40 \%$ do so, reaching peaks of $85 \%$. Another interesting fact is shown by the International Network of Education for Work (RIET), $63 \%$ of those who did telework would like to continue with this form.

Teleworking presents pros and cons for both companies and workers; for the former it lowers costs and promotes greater productivity, but it complicates the capacity for supervision and coordination. For the latter, it reduces transportation times and costs and improves the balance between work and personal life, but it is difficult to regulate work schedules and have the necessary computer tools.

\footnotetext{
"Visión de Futuro" Año 18, Volumen No 25 N 1, Enero - Junio 2021 - Pág 92 -106

URL de la Revista: http://visiondefuturo.fce.unam.edu.ar/index.php/visiondefuturo/index

URL del Documento: https://visiondefuturo.fce.unam.edu.ar/index. php/visiondefuturo/issue/view/19

ISSN 1668 - 8708 - Versión en Línea

E-mail: revistacientifica@fce.unam.edu.ar
} 
If teleworking is installed as an extended modality, it may not be enough with a law that guarantees the fulfillment of the obligations and the labor rights, it will also be necessary to think about a new culture of work that approaches in an integral way the relations between companies and employees, and in which the home, the family and the technology will be bigger protagonists than they showed until now.

\section{Methodology}

The present investigation is of qualitative type, we used the exploratory-descriptive and documentary methods, for which we reviewed books and articles related to the subject of the last 10 years, to determine the elements that conform the Quality of Labor Life, to compile and to systematize the information from the background, different definitions, importance and factors that impact it.

Then we select the articles that contain models to determine and measure the QWL. Finally, we carry out the Study and Comparative Analysis of the diverse models and schemes that we have relieved of the selected bibliography, with the purpose of constructing a refined and complete model that contains the main dimensions of the models that have been analyzed and tested, plus other dimensions of Continuous Improvement and Teleworking.

In the section State of the Art, we detail the publications selected for their interest in the contributions to the conceptual framework, to the new conditions or components considered for the study of the QWL and to the operational models that they present, considering the multidimensional nature of the concept of QWL.

From the theoretical framework of the Changes in the Dynamic Processes, produced by the Total Quality, we carried out a table with the dimensions and identified variables similar to the one of other authors, in order to be able to compare it and add them to the new model, as well as the effects of the quarantine by Covid-19 in people's work and therefore, in the Quality of Working Life.

In this way, we have elaborated a model that is as complete as possible, due to the greater quantity and quality of the factors or components of the QWL included, and which we hope will be useful for decision making.

From this integrating model, we built a digital questionnaire containing the dimensions indicated above and we carried out a pilot test of it to determine the level of understanding of the questions, which was satisfactory.

\footnotetext{
“Visión de Futuro" Año 18, Volumen No 25 N 1, Enero - Junio 2021 - Pág 91 -106

URL de la Revista: http://visiondefuturo.fce.unam.edu.ar/index.php/visiondefuturo/index

URL del Documento: https://visiondefuturo.fce.unam.edu.ar/index.php/visiondefuturo/issue/view/19

ISSN 1668 - 8708 - Versión en Línea

E-mail: revistacientifica@fce.unam.edu.ar
} 


\section{Results}

\section{Comparative table of operational models}

Based on the review of the work done, we took the CVT-GOHISALO-2010 model as a basis for our comparative study, because it is validated and has numerous precedents of its use in QWL studies.

In the comparison of the models analyzed in the work, we evaluated four aspects: a) whether the model stated dimensions, b) whether it specified variables within the dimensions, and $\mathrm{c}$ ) whether the authors presented an operational model, meaning an operational version of the variables in the form of items or questions that can be evaluated. Finally, we considered, d) whether the instrument had been validated and its reliability evaluated. This is shown in Table No. 1 below:

Table No. 1: Comparative of studied operational models

\begin{tabular}{l|c|c|c|c|}
\multicolumn{1}{|c|}{ Selected authors } & Dimensions & Variables & Operational Model & $\begin{array}{c}\text { Validation and } \\
\text { reliability }\end{array}$ \\
\hline Martínez, Oviedo, Luna & YES & YES & NO & NO \\
\hline Becerra & YES & YES & YES & NO \\
\hline Cruz & YES & NO & NO & NO \\
Granados & YES & YES & NO & NO \\
GOHISALO-2010 & YES & YES & YES & YES \\
GOHISALO-2018 & YES & YES & YES & YES \\
\hline \multicolumn{2}{r|}{ Source: Own Elaboration }
\end{tabular}

This comparative analysis has allowed us to choose the best model, according to the following inclusion criteria:

1. If the model includes an operational version, being the models of Becerra and GOHISALO (in its two versions) those that fulfill this criterion.

2. If the model has been validated and its reliability evaluated.

After applying the two defined criteria to the analyzed models, the two versions of the GOHISALO model (2010 and 2018) were left. These models are the ones that we took as a base to elaborate the superior model that we proposed as objective of the present work.

Likewise, we compared the two versions of the GOHISALO model with each other, in order to finally choose one. The main advantage of the short version of GOHISALO is that the total number of items in the questionnaire is reduced from 74 to 31 , and even so, the instrument remains reliable.

\footnotetext{
"Visión de Futuro" Año 18, Volumen No 25 Nº 1, Enero - Junio 2021 - Pág 92 -106

URL de la Revista: http://visiondefuturo.fce.unam.edu.ar/index.php/visiondefuturo/index

URL del Documento: https://visiondefuturo.fce.unam.edu.ar/index.php/visiondefuturo/issue/view/19

ISSN 1668 - 8708 - Versión en Línea

E-mail: revistacientifica@fce.unam.edu.ar
} 
In Table No. 2 we compare each dimension of both instruments and the number of variables included in each one:

Table No. 2: Comparison of the dimensions of the GOHISALO models

\begin{tabular}{|l|c|c|}
\hline \multicolumn{1}{c}{ Dimensions } & GOHISALO-2010 & GOHISALO-2018 \\
\hline Free time management & 5 & 2 \\
\hline Well-being achieved through work & 11 & 6 \\
\hline Worker's personal development & 8 & 3 \\
\hline Workplace integration & 10 & 3 \\
\hline Job satisfaction & 11 & 6 \\
\hline Safety at work & 15 & 5 \\
\hline Institutional support for the work & 14 & 6 \\
\hline Total number of variables & $\mathbf{7 4}$ & $\mathbf{3 1}$ \\
\hline
\end{tabular}

Source: Own Elaboration

By going from 74 variables to 31 , the total number of variables is reduced by $58 \%$. Having fewer variables considerably favors the realization of the study. It is important to emphasize that the reduced model contains the same dimensions as the original model but contemplating fewer variables in each one of them (Table No. 2) and, as we mentioned before, without losing its reliability.

We also compared the dimensions of the Dynamic Processes with the GOHISALO 2010 model, to see if they were included in it and we obtained Table No. 3.

Table No. 3: CVT-GOHISALO-2010 vs. Dynamic Processes

\begin{tabular}{|c|c|c|}
\hline & & $\begin{array}{l}\text { Included variables } \\
\text { (1) }\end{array}$ \\
\hline \multirow{7}{*}{$\begin{array}{l}\text { Dynamic } \\
\text { Processes }\end{array}$} & Leadership & 12 \\
\hline & Motivation & 13 \\
\hline & Conflict & 2 \\
\hline & Communication & 4 \\
\hline & Information & 1 \\
\hline & $\begin{array}{l}\text { Permanent } \\
\text { training }\end{array}$ & 2 \\
\hline & $\begin{array}{l}\text { Continuous } \\
\text { learning }\end{array}$ & 1 \\
\hline
\end{tabular}

(1) Number of variables referred to dynamic processes included in CVT-GOHISALO-2010

Source: Own Elaboration

\footnotetext{
"Visión de Futuro" Año 18, Volumen No 25 No 1, Enero - Junio 2021 - Pág 91 -106

URL de la Revista: http://visiondefuturo.fce.unam.edu.ar/index.php/visiondefuturo/index

URL del Documento: https://visiondefuturo.fce.unam.edu.ar/index.php/visiondefuturo/issue/view/19

ISSN 1668 - 8708 - Versión en Línea

E-mail: revistacientifica@fce.unam.edu.ar
} 
We observe that in the Training and Learning dimensions (which constitute Continuous Improvement), GOHISALO 2010 contemplates only 2 and 1 Dynamic Process variables, respectively. For this reason, we decided to complete the proposed integrative model, with these two dimensions and with the Telework dimension.

Summarizing then, with the aim of achieving an operational model that exceeds and integrates most of the dimensions identified as relevant to the study of the QWL, we decided to use the model CVT-GOHISALO-2018 (Brief), completed with a dimension referred to Continuous Improvement and another on the impact of quarantine by Covid-19 on the work of people. It's presented in Table No. 4.

Table No. 4: Questionnaire (Superior Integral Model of Quality of Working Life)

\begin{tabular}{|c|c|}
\hline NO. & Questions \\
\hline 1 & Proceso que se sigue para supervisar mi trabajo \\
\hline 2 & Trato que recibo de mis superiores \\
\hline 3 & Se me ha indicado de manera clara y precisa la forma en que debo de hacer mi trabajo \\
\hline 4 & $\begin{array}{l}\text { Recibo retroalimentación por parte de mis compañeros y superiores en cuanto a la evaluación } \\
\text { que hacen de mi trabajo }\end{array}$ \\
\hline 5 & $\begin{array}{l}\text { En mi organización se reconocen los esfuerzos de eficiencia y preparación con oportunidades } \\
\text { de promoción }\end{array}$ \\
\hline 6 & $\begin{array}{l}\text { Considero que tengo libertad para expresar mis opiniones en cuanto al trabajo sin temor a } \\
\text { represalias de mis jefes }\end{array}$ \\
\hline 7 & La forma en que están diseñados los procedimientos para realizar mi trabajo \\
\hline 8 & El salario que tengo \\
\hline 9 & Las condiciones físicas de mi área laboral (ruido, iluminación, limpieza, orden, etc.) \\
\hline 10 & El tipo de capacitación que recibo por parte de la organización \\
\hline 11 & $\begin{array}{l}\text { Considero que recibo en cantidad suficiente los insumos necesarios para la realización de mis } \\
\text { actividades laborales }\end{array}$ \\
\hline 12 & Trato que tengo con mis compañeros de trabajo \\
\hline 13 & En mi organización se respetan mis derechos laborales \\
\hline 14 & $\begin{array}{l}\text { Busco los mecanismos para quitar los obstáculos que identifico en el logro de mis objetivos y } \\
\text { metas de trabajo }\end{array}$ \\
\hline 15 & La forma de contratación, con que cuento en este momento \\
\hline 16 & Trabajar en esta organización (comparando con otras organizaciones que conozco) \\
\hline 17 & Las funciones que desempeño en esta organización \\
\hline 18 & El uso que hago en este trabajo de mis habilidades y potenciales \\
\hline 19 & El reconocimiento que recibo de otras personas por mi trabajo \\
\hline
\end{tabular}

\footnotetext{
"Visión de Futuro" Año 18, Volumen $\mathrm{N}^{0} 25$ N 1, Enero - Junio 2021 - Pág 92 -106

URL de la Revista: http://visiondefuturo.fce.unam.edu.ar/index.php/visiondefuturo/index

URL del Documento: https://visiondefuturo.fce.unam.edu.ar/index.php/visiondefuturo/issue/view/19

ISSN 1668 - 8708 - Versión en Línea

E-mail: revistacientifica@fce.unam.edu.ar
} 


\begin{tabular}{|c|c|}
\hline NO. & Q \\
\hline 20 & Mi desempeño como profesional en este trabajo \\
\hline 21 & La calidad de los servicios básicos de mi vivienda \\
\hline 22 & ¿Qué tanto percibo que mi trabajo es útil para otras personas? \\
\hline 23 & $\begin{array}{l}\text { Cuento con la integridad de mis capacidades físicas, mentales y sociales para el desempeño de } \\
\text { mis actividades diarias (vestir, caminar, trasladarse, alimentarse, etc.) }\end{array}$ \\
\hline 24 & Mi trabajo me permite acceder en cantidad y calidad a mis alimentos \\
\hline 25 & Mi trabajo contribuye con la buena imagen que tiene la organización ante sus usuarios \\
\hline 26 & El logro de mis objetivos con respecto al trabajo \\
\hline 27 & $\begin{array}{l}\text { Considero que el logro de satisfactores personales que he alcanzado se deben a mi trabajo en } \\
\text { la organización }\end{array}$ \\
\hline 28 & Mis potencialidades mejoran por estar en este trabajo \\
\hline 29 & $\begin{array}{l}\text { Considero que el trabajo me ha permitido brindar el cuidado necesario para conservar la } \\
\text { integridad de mis capacidades físicas, mentales y sociales }\end{array}$ \\
\hline 30 & $\begin{array}{l}\text { Mi trabajo me permite cumplir con las actividades que planeo para cuando estoy fuera del } \\
\text { horario de trabajo }\end{array}$ \\
\hline 31 & Mis actividades laborales me dan oportunidad de convivir con mi familia \\
\hline 32 & Se realizan capacitaciones en mi organización \\
\hline 33 & La capacitación que recibo de mi organización sobre: DETECCIÓN DE FALLAS es suficiente \\
\hline 34 & La capacitación que recibo de mi organización sobre: GESTIÓN DE CALIDAD es suficiente \\
\hline 35 & $\begin{array}{l}\text { La capacitación que recibo de mi organización sobre: RESOLUCIÓN DE PROBLEMAS es } \\
\text { suficiente }\end{array}$ \\
\hline 36 & En mi organización, se gestionan las necesidades y requerimientos de los clientes \\
\hline 37 & En mi organización, se gestionan las no conformidades \\
\hline 38 & Me interesa aprender más sobre mi tarea \\
\hline 39 & $\begin{array}{l}\text { Me interesa aprender más sobre la interrelación de mis tareas con otros procesos de la } \\
\text { organización }\end{array}$ \\
\hline 40 & Me interesa aprender más sobre la filosofía del Kaizen (Mejora Continua) \\
\hline 41 & ¿En qué medida la cuarentena por COVID-19 afectó el desarrollo de su trabajo? \\
\hline 42 & $\begin{array}{l}\text { ¿En este contexto de cuarentena, realizó teletrabajo o home office para el desarrollo de sus } \\
\text { tareas? }\end{array}$ \\
\hline 43 & ¿Cuál es su GRADO DE SATISFACCIÓN en relación al Teletrabajo? \\
\hline
\end{tabular}

Source: Own Elaboration

We conducted a pilot test of the resulting instrument in order to evaluate the understanding of the questions included. The results of this test were satisfactory and are presented below:

\footnotetext{
"Visión de Futuro" Año 18, Volumen No 25 No 1, Enero - Junio 2021 - Pág 91 -106

URL de la Revista: http://visiondefuturo.fce.unam.edu.ar/index.php/visiondefuturo/index

URL del Documento: https://visiondefuturo.fce.unam.edu.ar/index.php/visiondefuturo/issue/view/19

ISSN 1668 - 8708 - Versión en Línea

E-mail: revistacientifica@fce.unam.edu.ar
} 
1. When asked how easy/difficult it was for respondents to answer the questionnaire, $17 \%$ said it was very easy, $66 \%$ easy, $0 \%$ indifferent, $17 \%$ difficult and $0 \%$ extremely difficult.

2. Respondents identified the following areas for improvement in their comments:

- Improve usability from cell phones.

- Avoiding technical language.

- Group questions according to response scale.

- Carry out an induction in the participating organizations

All this provides valuable information to improve the research instrument.

\section{CONCLUSIONS}

1. The Comparative Analysis allowed us to expand our theoretical knowledge about the QWL:

- The concept of QWL is eminently multidimensional and there is no consensus on which dimensions define it.

- It is not materially possible to make a model that includes all the dimensions identified by the authors.

- CVT-GOHISALO-2010 is the model that has been validated and widely used in many QWL researches, but it has the disadvantage of its extension: 74 components. Therefore, other researchers have elaborated a short version of the same CVTGOHISALO-2018 with 31 components.

- The incorporation of all dynamic process factors and the impact of Covid-19 quarantine in the operational model would make it too extensive.

2. From this theoretical analysis of the models, it was possible to develop a transfer to a questionnaire as complete as possible to investigate and measure QWL:

- We built an operational model based on CVT-GOHISALO-2018 (Brief) and incorporated: a dimension on Continuous Improvement, composed by the factors of permanent training and continuous learning and a dimension to evaluate the impact of the quarantine by Covid-19, in the work of the people, which is presented in Table No. 4.

- We trust that this model of improvement will be useful for the decision making of the managers.

- The questionnaire resulting from the comprehensive model was developed in Google Forms (available at https://forms.gle/Zub6is3oNtM4TvW38) and was pilot tested to

\footnotetext{
"Visión de Futuro" Año 18, Volumen No 25 N 1, Enero - Junio 2021 - Pág 92 -106

URL de la Revista: http://visiondefuturo.fce.unam.edu.ar/index.php/visiondefuturo/index

URL del Documento: https://visiondefuturo.fce.unam.edu.ar/index.php/visiondefuturo/issue/view/19

ISSN 1668 - 8708 - Versión en Línea

E-mail: revistacientifica@fce.unam.edu.ar
} 
assess its understanding by respondents. The results of this test were satisfactory and useful for improving the evaluation instrument.

\section{Future lines of research}

As a subsequent stage to this project, it is foreseen the application of the questionnaire that has already been tested, for the study of the QWL in the organizations of the City of Córdoba. It is planned to work with a sample of the census of companies of the Production Ministry of the Province of Córdoba, selecting those located in our city.

\section{REFERENCES}

Please refer to articles in Spanish Bibliography.

\section{BIBLIOGRAPHICAL ABSTRACT}

Please refer to articles Spanish Biographical abstract. 